\title{
History of science, what is it and whatever for?
}

\author{
La historia de la ciencia: ¿Qué es y para qué?
}

\author{
Blanca Irais Uribe Mendoza*
}

Distant and far away as they might seem, history and science possess an indissoluble connection, born at the very instant these fields of knowledge are constituted. It is for this reason that, in the following lines, I aspire to provide the reader with clarity with respect to this interesting relationship, which can be found in scientific endeavors. To start with, we must understand what history really is.

History, as a discipline of the field of social sciences, reconstructs the past based on documents and evidence (verbal or material). This evidence is assessed, interpreted, questioned and connected to other facts, and is subjected to critical analysis targeting comprehension and explanation of the dynamics of societies in the past. When carrying out this task, the intent of the historian is to answer very specific questions arising from the present, proposed based on the requirements of his time. Therefore, historiography (which is history written based on investigation and reflection of the past) narrates, describes and explains the past in the light of the present.

\section{WHAT IS THE MEANING OF HISTORY OF SCIENCE?}

History of science is not a narration of chronologically related facts, neither is it a dialectic of problems and solutions of experimental practice, and nor is it a description of conjectures and refutations, or replacement of practices, theories, concepts or methods. It represents a historiographical narrative describing processes of evolution and transformation of human cognitive actions, describing historicity behind experimentation and theories which aspire to understand, apprehend and intervene in the world from the perspective of scientific rationality. ${ }^{1}$ In this sense, history of science explains the trajectory followed by human beings in order to find solutions to concrete problems as well as be acknowledged with aspects of reality. ${ }^{2}$

In narrative of history of science, epistemic and social interconnections are described; they constitute a diachronic content where scientific and technological transformations can only be explained by a net of relationships and causal successions of financial, political, material environmental, religious, spatial and epistemic nature.

Within the explicatory character of history of science, epistemology (the study of knowledge) incorporates a historical experience on construction, institutionalization and legitimacy of science's normative elements, their justification context, claim of truthfulness as well as practical, theoretical and methodological elements, without neglecting the socio-cultural explanation of exile or permanence of new conceptual criteria.

\section{HISTORY OF SCIENCE, WHATEVER FOR?}

In a conscious or unconscious fashion scientists use history of science to situate themselves at a specific point of the development of a certain knowledge, and from there move further on to new postulates which might lead to novel results, and eventually, to paradigm changes. ${ }^{3}$ Therefore, history of science possesses the ability to reveal procedures that become confrontations which trigger advances in science. In the XXI century trying to deal with technological and scientific exorbitance, society experiences uncertainty and disorientation before the unlimited ability of science and technology to intervene, modify and redesign the natural world. Even to this day, it is clear that technical and scientific innovations (of medical, telecommunications, food production and generally consumer goods nature) are causing severe environmental damage, especially

\footnotetext{
* Doctor in History and Science Philosophy UNAM. Institute of Research on University and Education, National Autonomous University of Mexico UNAM.
}

(C) 2017 Universidad Nacional Autónoma de México, [Facultad de Odontología]. This is an open access article under the CC BY-NCND license (http://creativecommons.org/licenses/by-nc-nd/4.0/).

This article can be read in its full version in the following page: http://www.medigraphic.com/facultadodontologiaunam 
when considering the existing vulnerability to control biotechnological innovations.

In the present, when facing this concern, history of science arrives to expose -from the past-cultural political, financial, spatial and material reasons or causes to explain why science and technology not only imposed themselves as valid knowledge to understand and explain the world, but furthermore to transform and commercialize it.

Therefore, the present demands from history both analysis and critical explanations which might question the positioning of technical and scientific knowledge within the frame of the present world.

History of science also meets the purpose to safeguard the heritage of local knowledge. This means that when scientific past of a region or country is obliterated or disappears, history of science recovers and finds practices, theories, proposals and achievements of moments and places with the intention of locating originality, innovation and historicity knowledge at a specific time and place.

Following this same trend, it so happens that within history of science, the construction process of a professional and scientific community unravels, thus possessing the ability to further unite identity and recognizance. This is the reason of finding ethos of the scientist (behavior, character, identity) in history of science; since, in history of science, as in general history, a landscape is sketched where human beings find recognizance and identity. This aspect is also related to the fact that history of science be a mirror reflecting terms with which science builds the images of the future which it aims to reach in the universe of nature and human beings. Derived from there is the fact that it might be useful to create and administer new higher education institutions as well as show the contents pertaining to each scientific profession, ${ }^{4,5}$ and where one of the uses of scientific memory can be precisely found.

On the other hand, history of science can be useful to visualize the manner in which human beings have established their relationship with the natural world, based on criteria established by scientific rationality, so that in it the following can be found: discursive, practical, theoretical and even ontological resignifications, which knowledge production grants live beings in time and space. ${ }^{6}$ Thus, history of science provides an account about how human beings have capitalized and administered nature, since the time of knowledge production.

\section{TO CONCLUDE}

History of science, is, in short, science itself and the building of its field as a discipline and profession.
In it, explanation is provided on how it is that science managed to be what it presently is, what role does the scientist play in society, how is it that science and scientists have transformed the world, and which have been the factors through which science became a valid instrument in order to understand it and measure it.

History of science not only provides an account of experimental, conceptual and cognitive evolution of science, in addition it manifests the capacity to explain how science has become inserted in society. In this sense, there is no divorce from a critical view into the factors that condition trajectories of science, but neither does it forget to narrate achievements of men and women who have rendered scientific knowledge the most effective tool to solve many of the great problems which society faces.

\section{REFERENCES}

1. Wartofsky M. The Relation between Philosophy and Science and History of Science. Boston Studies in the Philosophy of Science, 1977; 39: 717-737.

2. Estrada MM. Entrevista a Carlos López Beltrán. En: Uribe MB. El crisol de la ciencia y la tecnología. Voces y perspectivas desde la historia y la filosofía de la ciencia. México: UNAM. 2016.

3. Solís C. Razones e intereses. La historia de la ciencia después de Kuhn. Barcelona: Paidós. 1994.

4. Palomares TE. Los grupos científicos frente a su historia. Oralidad y memoria en el Instituto de Química de la Universidad Nacional Autónoma de México. Tesis de maestría, México: FFyL-UNAM. 2007.

5. Guevara FR. El uso de la historia en el quehacer científico. Una mirada a las obras históricas del biólogo Beltrán y del fisiólogo Izquierdo, México: UNAM. 2015.

6. Uribe MB. Apuntes para la historia de la bioartefactualidad animal. El caso de Dolly. En: Linares JE, Arriaga E. Aproximaciones interdisciplinarias a la bioartefactualidad. México: UNAM. 2016

\section{RECOMENDED READINGS}

- Carr E. ¿Qué es la historia? México: Siglo XXI. 1997. Ariel, España, 2010, p. 224.

- De Certeau M. La escritura de la historia, México: Universidad Iberoamericana, 1993.

- Galison P, Lorraine D. Objectivity. New York Cambridge, Massachussetts: Zona Books the MIT, 2007.

- Galison P, Stump JD. The disunity of Science: boundaries, contexts and power. Stanford: Stanford University Press, 1996.

- Guillaumin G. El surgimiento de la noción de evidencia. México: UNAM, 2005.

- Hartog F. Historia, memoria y crisis del tiempo. ¿Qué papel juega el historiador?". Revista Historia y Grafía. 2009; 33: 115-131.

- Martínez SF, Guillaumin G. Historia, filosofía y enseñanza de la ciencia. México: UNAM, 2005.
Mailing address:

Blanca Irais Uribe Mendoza

E-mail: blancaurme@gmail.com 